\title{
Deficiency of a Surface Membrane Glycoprotein (Mo1) in Man
}

\author{
Nava Dana, Robert F. Todd III, Jane Pitt, \\ Timothy A. Springer, and M. Amin Arnaout \\ Divisions of Nephrology and Cell Biology, Children's Hospital; \\ Division of Tumor Immunology and the Laboratory of \\ Membrane Immunochemistry, Dana Farber Cancer Institute; \\ Harvard Medical School, Boston, Massachusetts 02115; and \\ Division of Infectious Disease, Department of Pediatrics, \\ Columbia University College of Physicians \& Surgeons, \\ New York 10032
}

bstract. Deficiency of a granulocyte surface glycoprotein of 150,000-D had been associated with defective C3- and IgG-dependent phagocytosis in a patient with recurrent bacterial infections. By using monoclonal antibodies, we found that this patient's granulocytes, monocytes, and null cells were deficient in Mol (equivalent to OKM1 and Mac-1), a cell surface molecule consisting of two noncovalently linked glycoproteins of 155,000 and $94,000 \mathrm{D}$. The $155,000-\mathrm{D}$ subunit is closely associated with the human complement receptor that recognizes $\mathrm{C} 3 \mathrm{bi}$ and/or a further degradation product termed C3dg (C3bi receptor); the 94,000-D subunit has been shown to be shared, on normal cells, by two other surface membrane glycoproteins: lymphocyte function-associated antigen-1 (LFA-1) and P-150,95. Both subunits of Mol were deficient on the patient's granulocytes as determined by immunoprecipitation with subunit-specific monoclonal antibodies as well as fluorescence analysis. Mo1deficient monocytes, like granulocytes, had defective C3and IgG-dependent phagocytosis. Natural killing activity by the patient's peripheral blood leukocytes was normal. Mo1-deficient granulocytes and monocytes rosetted normally with sheep erythrocytes coated with C3bi. This

This work was presented in part at the Annual Meeting of the American Society for Clinical Investigation, 1 May 1983, Washington, DC. Dr. Dana is a recipient of a postdoctoral fellowship from the Arthritis Foundation. Dr. Arnaout is an Established Investigator of the American Heart Association. Address all correspondence to Dr. Arnaout, Children's Hospital, Boston, MA, 02115. 1983.

Received for publication 2 June 1983 and in revised form 2 September

J. Clin. Invest.

(C) The American Society for Clinical Investigation, Inc.

0021-9738/84/01/0153/07\$1.00

Volume 73, January 1984, 153-159 rosetting was totally inhibited by a mixture of anti-Mol and anti-C3b (the major fragment of $\mathrm{C} 3$ ) receptor antibodies but not by either antibody alone. Since monoclonal antibodies to the 155,000-D subunit of Mol can inhibit C3bi receptor binding, immune phagocytosis, opsonized zymosan-induced degranulation, and superoxide generation by normal phagocytes (functions which are defective in Mol-deficient cells), it appears likely that Mol deficiency may in part underlie the functional aberrations leading to recurrent bacterial infections in man.

\section{Introduction}

Mol is a cell surface glycoprotein present on human granulocytes, monocytes, and null cells (1). It consists of two noncovalently linked proteins of 155,000 and 94,000 molecular masses (2). Monoclonal antibodies to this antigen and to a similar surface antigen in the mouse and human (Mac-1) specifically inhibit complement C3bi-dependent rosette formation $(3,4)$. In addition, anti-Mol blocks phagocytosis by human granulocytes of C3- or IgG-opsonized particles as well as lysosomal enzyme release and superoxide generation by granulocytes in response to opsonized zymosan (3) (Arnaout, M. A., and J. Melamed, unpublished observations). Impaired phagocytosis and opsonized zymosan-induced degranulation and superoxide production were previously noted in granulocytes from a patient with recurrent bacterial infections (5). The patient's cells were found to be deficient in a surface glycoprotein of molecular mass of $\sim 150,000 \mathrm{D}(5)$. The similarities in the functional defects found in this patient and those produced in normal cells by anti-Mol led us to look for Mol on the patient's cells to gain more insight into the molecular mechanisms that led to the cellular functional aberrations detected in this patient. We found that: $(a)$ The patient's granulocytes, monocytes, and null cells were deficient in Mol. (b) Mol-deficient monocytes had impaired ability to ingest C3- or IgG-coated particles. (c) Rosette formation between the patient's phagocytes and sheep eryth- 
rocytes coated with $\mathrm{C} 3 \mathrm{bi}^{1}$ (a fragment of $\mathrm{C} 3 \mathrm{~b}$ generated upon cleavage of surface-bound $\mathrm{C} 3 \mathrm{~b}$ by factors I and $\mathrm{H}$ ) was totally inhibited by a mixture of anti-Mol and a polyclonal antibody to the receptor for the major cleavage product of $\mathrm{C} 3(\mathrm{C} 3 \mathrm{~b})$, but not by either antibody alone. $(d)$ Peripheral blood leukocytes (PBL) deficient in Mol had normal natural killing (NK) activity.

\section{Methods}

Cell separation. Human neutrophils were prepared from EDTA anticoagulated venous blood by Ficoll-Hypaque centrifugation followed by hypotonic lysis of the erythrocyte pellet (6). Monocytes were isolated from the interphase mononuclear cell fraction by adherence to plastic petri dishes (1). A null cell-enriched population was isolated from mononuclear cells by binding of complement fixing monoclonal antibodies to T12 (7), I-2 (8) and Mo2 (1) surface markers (at 1:100 dilutions each, for $30 \mathrm{~min}$ at $4^{\circ} \mathrm{C}$ ), followed by complement lysis (rabbit complement, Pel-Freeze Biologicals, Rogers, AR) for $60 \mathrm{~min}$ at $37^{\circ} \mathrm{C}$. These steps depleted $\mathrm{T}$ and $\mathrm{B}$ lymphocytes and monocytes. The remaining cells were enriched for Mo1-positive and Mo2-negative null cells.

Monoclonal antibodies and heteroantisera. Monoclonal antibodies to Mo1, Mo2, Mo5, and Mac-1 were produced as previously described $(9,10)$. The OKM1O monoclonal antibody was obtained from Ortho Pharmaceutical (Raritan, NJ). Two additional monoclonal antibodies to Mol were kindly provided by Dr. J. Griffin, of the Dana Farber Cancer Institute. The $\mathrm{F}\left(\mathrm{ab}^{\prime}\right)_{2}$ fragment of IgG2a anti-Mol and anti-Mo5 were generated by pepsin digestion followed by gel filtration (11). The TS1/18 monoclonal antibody to the 94,000-D subunit of lymphocyte function-associated antigen-1 (LFA-1) and Mo1/Mac-1/OKM1 was produced as described (12). A $F\left(a^{\prime}\right)_{2}$ fragment of rabbit IgG directed against the human $\mathrm{C} 3 \mathrm{~b}$ receptor (anti-CR1), was a generous gift of Dr. D. Fearon, Brigham and Women's Hospital, Boston, MA (13).

Immunoprecipitation. Intact neutrophils were treated with diisopropylfluorophosphate and then ${ }^{125}$ I-surface labeled with Iodogen (Pierce Chemical Co., Rockford, IL) as previously described (5). ${ }^{125}$ I-incorporation was comparable in patient and control cells (data not shown). After labeling, cells were solubilized in 0.5\% Non-Idet P40 (NP40) in phosphate-buffered saline (PBS) and the lysates centrifuged at 105,000 $g$ for $30 \mathrm{~min}$. The supernatants were precleared with immune complexes consisting of a control mouse monoclonal antibody, rabbit IgG antimouse Ig, and heat-inactivated formalin-fixed Staphylococcus aureus. Precleared lysates were then incubated for 12-16 h with the specific monoclonal antibody. Rabbit antiserum to mouse Ig or a rat, antimouse kappa chain monoclonal antibody was added and incubation continued for $1 \mathrm{~h}$ at $4^{\circ} \mathrm{C}$, followed by $S$. aureus $\left(30 \mathrm{~min}, 4^{\circ} \mathrm{C}\right)$. The insolubilized immune complexes were washed four times with PBS containing $2 \mathrm{mM}$ phenyl-methyl-sulfonyl-fluoride and $0.1 \%$ Non-Idet P40 (NP40), and then extracted by boiling in Tris buffer, $\mathrm{pH}=6.8$ (sample buffer), containing $2 \%$ sodium dodecyl sulfate and $5 \%$ 2-mercaptoethanol. Eluates were electrophoresed on polyacrylamide gels as described (14).

Immunofluorescence studies. Indirect immunofluorescence of intact

1. Abbreviations used in this paper: $\mathrm{C} 3 \mathrm{~b}$, the major fragment of $\mathrm{C} 3$; $\mathrm{C} 3 \mathrm{bi}$, a fragment of $\mathrm{C} 3 \mathrm{~b}$ generated upon cleavage of surface-bound $\mathrm{C} 3 \mathrm{~b}$ by factors I and $\mathrm{H}$; C3bi receptor, a complement receptor that recognizes $\mathrm{C} 3 \mathrm{bi}$ and/or a further degradation product termed C3dg; $\mathrm{C} 3 \mathrm{~d}$ receptor, a receptor specific for the $\mathrm{C} 3 \mathrm{~d}$ fragment of $\mathrm{C} 3 ; \mathrm{CR}$, the $\mathrm{C} 3 \mathrm{~b}$ receptor; E, sheep erythrocytes; EAC43b, sheep erythrocytes coated with C3b; EAC43bi, C3bi-coated sheep erythrocytes; EAC43d, C3d-coated sheep erythrocytes; ElgG, sheep erythrocytes coated with rabbit IgG anti-E; NK, natural killing, ORO, oil red $O$. cells or cells permeabilized with methanol (to detect intracellular antigen) (15) was done by using the monoclonal antibodies and fluoresceinconjugated, goat anti-mouse IgG and IgM as previously described (1). Staining patterns of cell populations were generated by using a FACS1 cytofluorograph (Becton-Dickinson \& Co., Westwood, MA).

Complement or IgG-coated particles. Sheep erythrocytes (E) in Alsever's solution were obtained from M. A. Bioproducts (Walkersville, MD). IgG rabbit antibody directed to $\mathrm{E}$ was purchased from Cordis Laboratories (Miami, FL) and serum made by immunizing rabbits with E stroma (16) was used as a source of IgM antibody to E.

Sheep erythrocytes coated with rabbit IgG anti-E (EIgG) were made by incubating $E$ with the highest, nonagglutinating concentration of antibody in PBS for $15 \mathrm{~min}$ at $37^{\circ} \mathrm{C}$. Cells were then washed several times in PBS.

Sheep erythrocytes coated with C3b (EAC43b) were made by first incubating $E$ with rabbit anti-E IgM antibody. This was followed by sequential incubation with guinea pig $\mathrm{C} 1$, human $\mathrm{C} 4$, guinea pig $\mathrm{C} 2$, and then human $\mathrm{C} 3$ as described by Rapp and Borsos (16). $\mathrm{Cl}$ and $\mathrm{C} 2$ were allowed to dissociate by $2 \mathrm{~h}$-incubation at $37^{\circ} \mathrm{C}$ in veronal-buffered saline containing $10 \mathrm{mM}$ EDTA.

C3bi-coated sheep erythrocytes (EAC43bi) were made by incubating EAC43b with purified factor $\mathrm{I}(10 \mu \mathrm{g} / \mathrm{ml})$ and factor $\mathrm{H}(50 \mu \mathrm{g} / \mathrm{ml})(17)$ in Hanks' balanced salt solution containing $\mathrm{Ca}(1.27 \mathrm{mM})$ and $\mathrm{Mg}(1.23$ $\mathrm{mM}$ ) (HBSS) for $1 \mathrm{~h}$ at $37^{\circ} \mathrm{C}$ as described (3). Alternatively, EAC43bi were generated by incubating EAC43b in whole plasma that was extensively preabsorbed with antibody-coated sheep erythrocytes at $0^{\circ} \mathrm{C}$. $1.5 \times 10^{8}$ EAC43b cells were incubated with $200 \mu \mathrm{l}$ of preabsorbed human EDTA plasma at 1:10 dilution (as a source of factors $\mathrm{H}$ and $\mathrm{I}$ ) for $30 \mathrm{~min}$ at $37^{\circ} \mathrm{C}$ followed by several washes in HBSS containing $1 \mathrm{mg} / \mathrm{ml}$ soybean trypsin inhibitor (Worthington). EAC43bi did not bind to human erythrocytes (18) but rosetted with human granulocytes and monocytes. Rosetting of EAC43bi with normal phagocytes was inhibited by monoclonal antibodies to Mol but not by a rabbit antibody to the human $\mathrm{C} 3 \mathrm{~b}$ receptor (anti-CR1).

C3d-coated sheep erythrocytes (EAC43d) were obtained by incubating EAC43bi with TPCK-trypsin (Millipore Co., Freehold, NJ) at $0.1 \mu \mathrm{g} /$ $\mathrm{ml}$ in PBS for $45 \mathrm{~min}$ at $37^{\circ} \mathrm{C}$ (13). EAC43d cells did not rosette with human neutrophils but rosetted strongly with Raji cells.

Serum-opsonized lipopolysaccharide-coated oil red O (ORO) particles were prepared as previously described (19).

Rosetting. Granulocytes and monocytes were kept at $4 \times 10^{6} / \mathrm{ml}$ in HBSS, $2 \mathrm{mg} / \mathrm{ml}$ bovine serum albumin, and $1 \mathrm{mg} / \mathrm{ml}$ soybean trypsin inhibitor (Millipore Corp.). $25 \mu \mathrm{l}$ of cells were incubated with $3 \mu \mathrm{g} \mathrm{F}\left(\mathrm{ab}^{\prime}\right)_{2}$ anti-Mol, anti-Mo5, or $2 \mu \mathrm{g}$ of $\mathrm{F}\left(\mathrm{ab}^{\prime}\right)_{2}$ anti-CR1 for $20 \mathrm{~min}$ at room temperature, after which $15 \mu \mathrm{l}$ of indicator $\mathrm{E}$ at $1.5 \times 10^{8} / \mathrm{ml}$ were added and the mixture incubated for $40 \mathrm{~min}$ at $37^{\circ} \mathrm{C}$. To assess rosette formation, the cells were gently resuspended and examined using a hemocytometer. Binding of three or more $\mathrm{E}$ to a leukocyte was considered a rosette.

Phagocytosis. One million monocytes suspended in $100 \mu \mathrm{l}$ of RPMI1640 were incubated with or without $5 \mu \mathrm{g}$ of $\mathrm{F}\left(\mathrm{ab}^{\prime}\right)_{2}$ anti-Mol or control monoclonal antibody for $20 \mathrm{~min}$ at room temperature. $50 \mu \mathrm{l}$ of EIgG at $2 \times 10^{8} / \mathrm{ml}$ were then added and the mixture incubated at $37^{\circ} \mathrm{C}$ for $1 \mathrm{~h}$. Noningested E were hypotonically lysed with $0.0375 \mathrm{M}$ sodium chloride for $5 \mathrm{~s}$, after which isotonicity was established with $3 \mathrm{M}$ sodium chloride (20). Wright-stained cells were then counted to determine the percentage of cells that ingested one or more $\mathrm{E}$.

Phagocytosis of C3-opsonized ORO particles by patient or control monocytes was performed as previously described (19).

NK assay. The ability of the patient's PBL to effect NK of the target cell K562 was compared with normal control PBL. K562 cells 
were labeled with chromium 51 and incubated with PBL at various effector to target cell ratios for $4 \mathrm{~h}$ at $37^{\circ} \mathrm{C}(21)$. Target killing was determined by 51 chromium release into the media. Percent lysis was calculated as previously reported (21).

\section{Results}

Immunoprecipitation of granulocyte membrane proteins by monoclonal antibodies. A monoclonal antibody to Mol immunoprecipitated from ${ }^{125}$ I-surface-labeled normal granulocyte lysates, two noncovalently linked glycoproteins of 155 and 94 kD (Fig. 1 $A$ ). By using this same antibody, no bands were immunoprecipitated from the patient's ${ }^{125}$ I-labeled granuloctyes (Fig. 1 $A$ ). This monoclonal anti-Mol reacts only with the 155$\mathrm{kD}$ glycoprotein (3). To determine if the patient's cells were also missing the 94-kD subunit, a monoclonal antibody reactive with the 94-kD subunit of Mol/OKMl was used. This anti94-kD antibody immunoprecipitated from normal cells the two subunits of Mol as well as two other surface proteins which share the same 94-kD subunit with OKM1/Mol, namely LFA1 (subunits of 177 and $95 \mathrm{kD}$ ) and P-150,95 (subunits of 150 and $95 \mathrm{kD}$ ) (Fig. $1 B$, lane $f$ ) (22). No radiolabeled bands were seen with the patient's cells (Fig. $1 B$, lane $c$ ). These data demonstrate that the surface of the patient's granulocytes is deficient in both the 155 and $94 \mathrm{kD}$ polypeptides of Mol antigen as determined by subunit-specific monoclonal antibodies. To determine if the patient's neutrophils totally lack Mol, a more sensitive radioimmunoassay was used (3). Increasing amounts of ${ }^{125} \mathrm{I}-\mathrm{Fab}^{\prime}$ anti-Mol were incubated with the patient's granulocytes in the absence or presence of unlabeled Fab' anti-Mol (100-fold molar excess). Scatchard analysis of the binding data revealed that the patient has 7,000 $\pm 3,000 \mathrm{Mol}$ sites/cell (mean \pm SD) vs $65,000 \pm 7,000$ (mean \pm SD) for granulocytes from nine random individuals. These data indicate that the patient is deficient but not totally lacking the $155-\mathrm{kD}$ subunit of Mol.

Analysis of cell surface antigens by immunofluorescence. Fluorescence analysis confirmed that the patient's granulocytes were deficient in Mol, but expressed normal amounts of other leukocyte markers including Mo5, J5, and beta ${ }_{2}$-microglobulin (data not shown). The patient's granulocytes were also deficient in the equivalent Mac-1 antigen (data not shown). The patient's monocytes and null cells were also deficient in Mol when studied by indirect immunofluorescence technique. As can be seen in Fig. 2, immunofluorescent staining with anti-Mo2 (a monocytespecific surface marker) of both the patient's and control monocytes were comparable; yet, only the control monocytes had detectable staining with anti-Mol. Similarly, no anti-Mol staining was detected on the patient's null cell population. This population was defined by selecting the mononuclear cells which were T12-, Ia-, and Mo2-negative as described in Methods. A similar null cell population, which was isolated in parallel from normal control blood, had detectable immunofluorescent staining with the anti-Mol antibody (Fig. 2 B).

The possibility that the patient's cells had normal amounts of an altered Mol protein deficient in only one epitope was rendered unlikely by the use of independent monoclonal an-

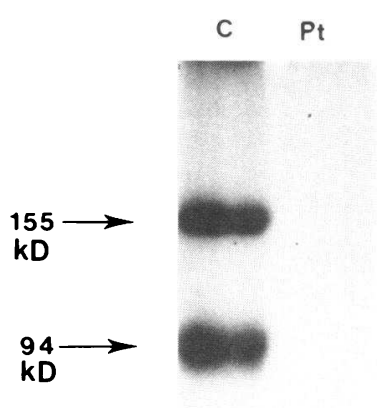

Figure $1 \mathrm{~A}$. Radioautograph of a $7.5 \%$ sodium dodecyl sulfatepolyacrylamide gel electrophoresis of anti-Mol immunoprecipitates from ${ }^{125}$ I-labeled granulocyte lysates from control (left lane) and patient (right lane).

tibodies. Five separate monoclonal antibodies reactive with the Mol glycoprotein on normal cells failed to bind to patient's granulocytes as determined by indirect immunofluorescence analysis (data not shown).

One reason for the surface deficiency of Mol on the patient's cells could be that the antigen is sequestered in an intracellular

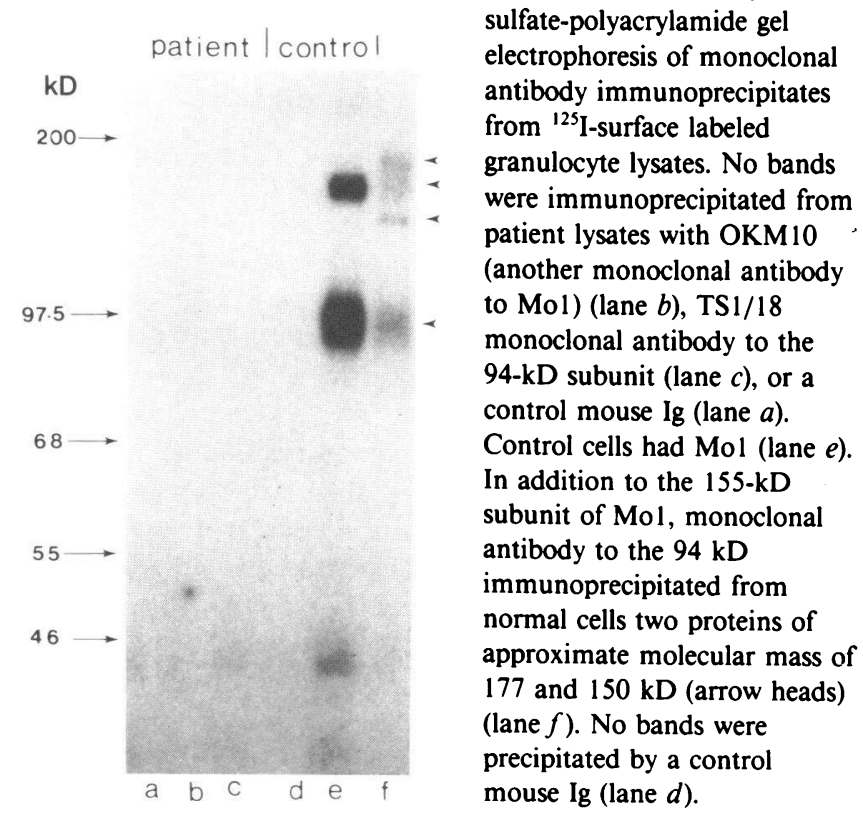

Figure 1 B. Radioautography of a $7 \%$ sodium dodecyl sulfate-polyacrylamide gel electrophoresis of monoclonal antibody immunoprecipitates from ${ }^{125}$ I-surface labeled granulocyte lysates. No bands were immunoprecipitated from patient lysates with OKM 10 (another monoclonal antibody to Mol) (lane $b$ ), TS1/18 monoclonal antibody to the 94-kD subunit (lane $c$ ), or a control mouse Ig (lane $a$ ). Control cells had Mol (lane $e$ ). In addition to the $155-\mathrm{kD}$ subunit of Mol, monoclonal antibody to the $94 \mathrm{kD}$ immunoprecipitated from normal cells two proteins of approximate molecular mass of 177 and $150 \mathrm{kD}$ (arrow heads) (lane $f$ ). No bands were mouse Ig (lane $d$ ). 
A.

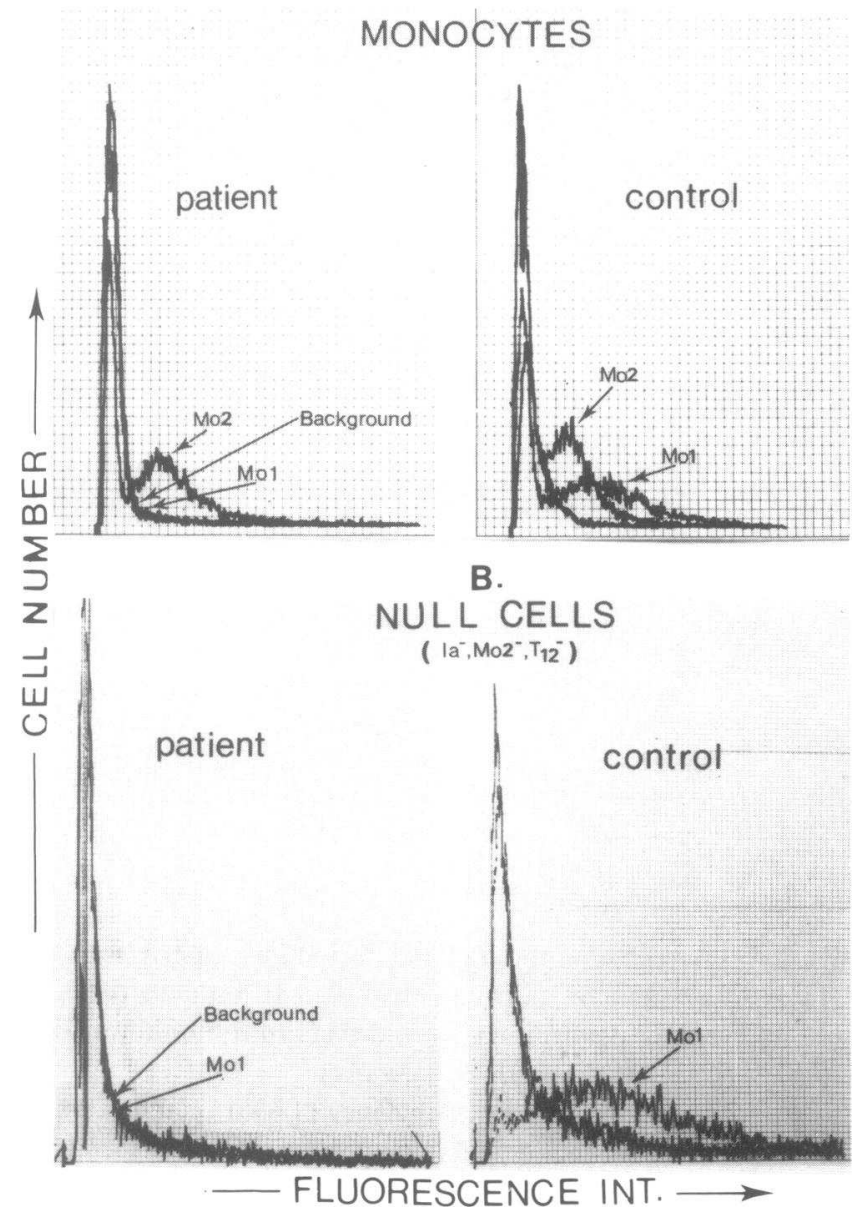

Figure 2. Immunofluorescent flow cytometry analysis of patient and control cells by using monoclonal antibodies to cell surface structures (A) Fluorescence staining of patient (left) and control (right) monocytes with monoclonal antibodies to $\mathrm{Mol}$ and $\mathrm{Mo} 2$ (monocyte specific). No fluorescence on patient's cells is noted when a monoclonal antibody to Mol is used. (B) Similar analysis reveals no fluorescence with monoclonal antibody to Mol on patient's null cellenriched population.

pool and therefore, inaccessible to surface iodination or fluorescence analysis. To rule out this possibility, both normal and patient granulocytes were rendered permeable to the two subunitspecific monoclonal antibodies to Mol by pretreatment with methanol (15), followed by indirect immunofluorescence analysis. On normal cells, there were appreciable levels of intracytoplasmic staining in addition to that detectable on the surface membrane as seen by fluorescence microscopy and quantitated by FACS- 1 cytofluorography. With the patient's cells, however, there was no measurable intracellular fluorescence over background (data not shown).

Detection of complement and $F_{c}$ receptors on Mol-deficient phagocytes. Since it was previously shown that monoclonal antibodies to Mol and Mac-1 specifically block C3bi receptormediated rosette formation with normal cells $(3,4)$, the ability of Mol-deficient cells to rosette with erythrocytes coated with C3bi was examined. As can be seen in Table I, both the patient's granulocytes and monocytes rosetted normally with EIgG or EAC43b. The patient's cells also rosetted normally with EAC43bi. Percent rosetting was not inhibited by an optimal concentration of either anti-CR 1 or anti-Mol (Table I). However, when the two antibodies were used together, no C3bi-dependent rosetting was seen with the patient's cells. Furthermore, EAC43bi binding was not mediated by an abnormally expressed receptor specific for the C3d fragment of C3 (C3d receptor) since no rosetting of EAC43d to the patient's granulocytes was seen. It appears likely, therefore, that binding of EAC43bi to the patient's phagocytes is mediated by the $\mathrm{C} 3 \mathrm{~b}$ receptor and dependent on small amounts of Mol antigen detected by this inhibition assay. In the presence of anti-CR 1 or anti-Mol alone, EAC43bi binding is dependent on $\mathrm{Mol}$ or mediated by $\mathrm{C} 3 \mathrm{~b}$ receptor, respectively.

Phagocytosis and NK activity by Mol-deficient cells. Ingestion of serum-opsonized ORO particles by the patient's monocytes was significantly depressed (Table II), a finding similar to that noted in his granulocytes (5). Ingestion of EIgG by patient's monocytes was also significantly reduced (Table II). Normal monocytes treated with anti-Mol showed a similar impairment in ingestion of serum-opsonized ORO or of EIgG. Inhibition of IgG phagocytosis was more striking at low IgG input (data not shown).

Since PBL enriched for null cells were deficient in Mol expression, it was of interest to determine if this deficiency was associated with an impairment of NK, a function attributed to M1 (Mol) positive null cells (23). Both patient and control cells mediated comparable degrees of lysis against K562 target cells indicating that deficiency of surface Mol does not alter the cells ability to perform NK (Fig. 3).

\section{Discussion}

Several patients with recurrent bacterial infections associated with deficiencies of granulocyte proteins have been described $(5,24,25,26)$. We used monoclonal antibodies to further characterize the functional defects in our patient. This study demonstrates the deficiency of a surface membrane glycoprotein, Mol, on this patient's granulocytes, monocytes, and null cells. The patient's granulocytes have an impaired capacity to ingest C3-opsonized particles such as zymosan, lipopolysaccharidecoated ORO, as well as particles coated with IgG. Zymosaninduced superoxide generation and lysozomal enzyme release are also depressed in Mol-deficient granulocytes (5). The patient's monocytes demonstrate a similar impairment of phagocytic function (Table II). NK activity by the patient's PBL was normal (Fig. 3), in agreement with in vitro studies in which pretreating PBL with anti-Mac-1 (27) or anti-Mol (Todd, R. F., III, unpublished data) did not interfere with their NK activity. 
Table I. Percentage of Cells Rosetting with IgG-, C3b-, or C3bi-coated Sheep Erythrocytes

\begin{tabular}{|c|c|c|c|c|c|c|}
\hline & \multirow[b]{2}{*}{ ElgG } & \multirow[b]{2}{*}{ EAC43b } & \multicolumn{4}{|c|}{ EAC43bi } \\
\hline & & & Buffer & $\begin{array}{l}\text { Buffer } \\
+F\left(a^{\prime}\right)_{2} \text { anti-CR } 1 \ddagger\end{array}$ & $\begin{array}{l}\text { Buffer } \\
+F\left(a b^{\prime}\right)_{2} \text { anti-Mol }\end{array}$ & $\begin{array}{l}\text { Buffer } \\
\text { + Anti-CR1 + Anti-Mol }\end{array}$ \\
\hline \multicolumn{7}{|c|}{ Granulocytes } \\
\hline Patient & $90^{*}$ & 64 & 41 & 39 & 41 & 1 \\
\hline Control & 88 & 65 & 39 & 44 & 11 & 2 \\
\hline \multicolumn{7}{|l|}{ Monocytes } \\
\hline Patient & 62 & 65 & 46 & 45 & 43 & NT§ \\
\hline Control & 74 & 72 & 30 & 30 & 10 & NT \\
\hline
\end{tabular}

* Values are the means of two separate determinations. No rosetting was seen between patient or control granulocytes and unopsonized sheep erythrocytes (data not shown).

¥ Anti-CR1 was used at a concentration that produced $80 \%$ inhibition of EAC43b rosetting with granulocytes and monocytes.

$\S$ Not tested.

On normal cells, anti-Mol, anti-Mac-1 or anti-OKM10 effectively blocked C3bi receptor-depedent rosette formation suggesting that Mol/Mac-1/OKM1 are closely associated $(3,4)$ or identical (28) with the $\mathrm{C} 3 \mathrm{bi}$ receptor. It has also been suggested that EAC43bi can bind to the C3b receptor $(29,30,31)$. We therefore examined the ability of the patient's phagocytes to form rosettes with EAC43bi. Percent rosetting of the patient's granulocytes and monocytes with EAC43bi in the presence of optimal concentrations of either anti-Mol or anti-CR1 alone was within normal limits (Table I). No rosetting was seen, however, in the presence of the two combined antibodies. This suggests that under the conditions used, and in the presence of anti-CR1, the small amounts of the 155-kD subunit of Mol present on the patient's cells can mediate the normal degree of EAC43bi-dependent rosetting obtained. The normal degree of rosetting seen with the patient (but not control) phagocytes in the presence of anti-Mol is not due to an increase in C3b receptor number (5) but may be due to an increased affinity of the patient's $\mathrm{C} 3 \mathrm{~b}$ receptors to $\mathrm{C} 3 \mathrm{bi}$. This may reflect a compensatory mechanism in Mol-deficiency states.

Structural studies revealed that the patient's cells were deficient in the two subunits of Mol antigen (Fig. 1). A monoclonal

Table II. Phagocytosis by Patient and Control Monocytes

\begin{tabular}{lll} 
& \multicolumn{2}{c}{ Stimulus } \\
\cline { 2 - 3 } & C3-coated ORO & $\begin{array}{l}\text { IgG-coated } \\
\text { erythrocytes }\end{array}$ \\
& $\mu g$ ORO ingested $/ 10^{7}$ cells $/$ min & \% of cells ingesting \\
Patient & $26^{*}$ & $28 \pm 5 \ddagger$ \\
Control & 70 & $64 \pm 9$ \\
\hline
\end{tabular}

* Values represent mean of two separate determinations. $¥$ Values represent mean \pm SD of triplicate determinations. antibody to the 94-kD beta subunit of Mol/OKM1 reacts not only with Mol but also with LFA-1 (alpha subunit of 177,000$\mathrm{D}$ glycoprotein) and possibly, with a third surface protein, P150,95 (alpha subunit of 150,000 D) (Fig. 1 B). Mol/OKM1, LFA-1, and P150,95 share the same $94-\mathrm{kD}$ beta subunit (22). None of these proteins were immunoprecipitated from the patient's granulocytes by antibody to the $94-\mathrm{kD}$ subunit. The patient's granulocytes and monocytes were also deficient in LFA1 when a monoclonal antibody specific for the 177,000-D alpha subunit was used (Arnaout, M. A., C. Terhorst, J. Pitt, and

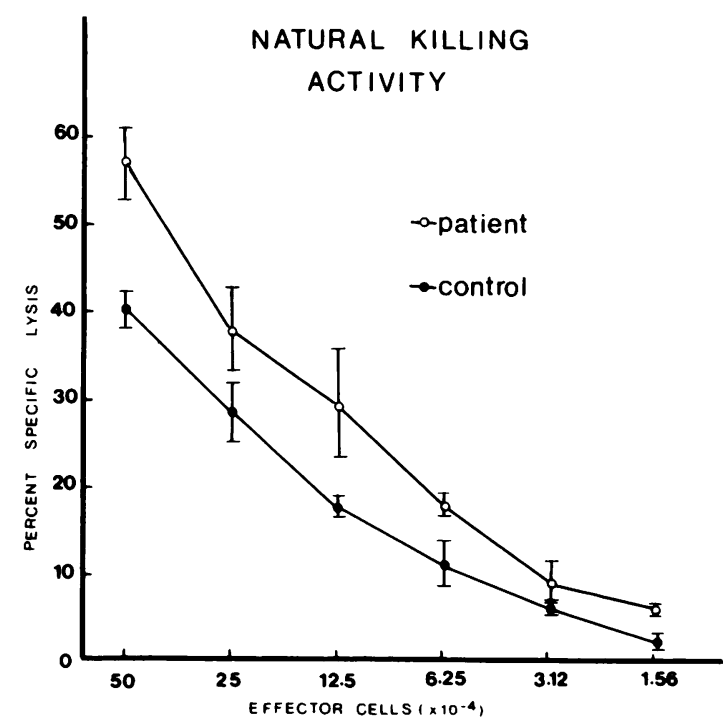

Figure 3. NK of K-562 target cells by patient and control PBL \pm SD (triplicate determinations). Over a wide range of effector to target cell ratios, no decrease in NK activity is noted in the Mol-deficient patient cell population. Spontaneous lysis was always $<5 \%$ of total lysis. Similar results were obtained in one other experiment. 
R. F. Todd III, manuscript in preparation). It is possible that deficiency of the $94-\mathrm{kD}$ glycoprotein may be the primary defect in this disease. During biosynthesis, association of the 94-kD subunit with Mo1, LFA-1, and P150,95 takes place (22) and may be necessary for the stable surface expression or function of these molecules.

Monoclonal antibodies to the $155,000-\mathrm{D}$ subunit of Mol inhibited phagocytosis of C3- or IgG-coated particles as well as opsonized zymosan-induced, lysozomal enzyme release and superoxide generation by normal cells (3) (Arnaout, M. A., and J. Melamed, unpublished observations). Inhibition of IgG-dependent phagocytosis was more pronounced at low rather than high IgG input. The role of Mol in IgG-dependent phagocytosis may be explained if $\mathrm{Mol}$ also functions in promoting adherence between certain surfaces and phagocytic cells (3). Of interest is that LFA-1, a structurally similar molecule, appears to serve such a function on lymphocytes $(12,32)$.

The anti-Mol-induced functional defects on normal phagocytes were similar to those observed in Mol-deficient cells. These findings suggest an association between deficiency of the 155,000$\mathrm{D}$ piece of Mol and the observed functional defects seen in the patient's phagocytes. However, it should be noted that if deficiency of the $94-\mathrm{kD}$ subunit is the primary defect, this may have a pleiotropic effect. The $94 \mathrm{kD}$ is common to three different surface antigens: Mo1, LFA-1, and P150,95. Immunoprecipitation studies indicate that at least two and possibly all three are deficient from the patient's granulocytes. It is possible that deficiency of these additional glycoproteins could also contribute to the observed functional defects.

Note added in proof. Three more patients with recurrent bacterial infections and Mol deficiency were recently found (Ross, G. D., R. A. Thompson, M. J. Walport, R. H. Ward, J. lida, S. L. Newman, R. A. Harrison, and P. J. Lachmann, manuscript submitted for publication).

\section{Acknowledgments}

We are indebted to Dr. Harvey R. Colten for his support and helpful discussions; the patient and his family for their enthusiastic cooperation through this study; and Ms. Helen P. Hourihan for secretarial assistance.

This research was supported by U. S. Public Health Service grants CA09172, CA33555, CA31798, AI17452, AI05877, AI15033, and HL22487.

\section{References}

1. Todd, R. F., III, L. M. Nadler, and S. F. Schlossman. 1981. Antigens on human monocytes identified by monoclonal antibodies. $J$. Immunol. 126:1435-1442.

2. Todd, R. F., III, A. van Agthoven, S. F. Schlossman, and C. Terhorst. 1982. Structural analysis of differentiation antigens Mol and Mo2 on human monocytes. Hybridoma. 1:329-337.

3. Arnaout, M. A., R. F. Todd III, N. Dana, J. Melamed, S. F. Schlossman, and H. R. Colten. 1983. Inhibition of phagocytosis of complement C3- or IgG-coated particles and of C3bi binding by monoclonal antibodies to a monocyte-granulocyte membrane glycoprotein (Mol). J. Clin. Invest. 72:171-179.

4. Beller, D. I., T. A. Springer, and R. D. Schreiber. 1982. AntiMac-1 selectively inhibits the mouse and human type three complement receptor. J. Exp. Med. i56:1000-1009.

5. Arnaout, M. A., J. Pitt, H. J. Cohen, J. Melamed, F. S. Rosen, and H. R. Colten. 1982. Deficiency of a granulocyte-membrane glycoprotein (gp150) in a boy with recurrent bacterial infections. $N$ Engl. J. Med. 306:693-699.

6. Boyum, A. 1968. Isolation of mononuclear cells and granulocytes from human blood. Scand. J. Clin. Lab. Invest. 21(Suppl. 19):77-89.

7. Reinherz, E. L., S. Meuer, K. A. Fitzgerald, R. E. Hussey, H. Levine, and S. F. Schlossman. 1982. Antigen recognition by human $T$ lymphocytes. Cell. 30:735-743.

8. Nadler, L. M., P. Stashenko, R. Hardy, J. Pesando, E. J. Yunis, and S. F. Schlossman. 1981. Monoclonal antibodies defining serologically distinct HLA-D/DR related Ia-like antigens in man. Hum. Immunol. 1:77-90.

9. Todd, R. F., III, and S. F. Schlossman. 1982. Differentiation antigens on human monocytes and macrophages defined by monoclonal antibodies. In Mononuclear Phagocytic Biology. A. Volkman, editor. Marcel-Dekker, New York. In press.

10. Springer, T., F. Galfre, D. S. Secher, and C. Milstein. 1979. Mac-1: a macrophage differentiation antigen defined by monoclonal antibody. Eur. J. Immunol. 9:301-306.

11. Stanworth, D. R., and M. W. Turner. 1978. Immunochemical analysis. In Handbook of Experimental Immunology. D. M. Weir, editor. Blackwell, Oxford. 25.

12. Sanchez-Madrid, F., A. M. Krensky, C. F. Ware, E. Robbins, J. L. Strominger, S. J. Burakoff, and T. A. Springer. 1982. Three distinct antigens associated with human T lymphocyte-mediated cytolysis: LFA1, LFA, and LFA-3. Proc. Natl. Acad. Sci. USA. 79:7489-7493.

13. Fearon, D. T. 1980. Identification of the membrane glycoprotein that is the $\mathrm{C} 3 \mathrm{~b}$ receptor of the human erythrocyte, polymorphonuclear leukocyte, B lymphocytes, and monocyte. J. Exp. Med. 152:20-30.

14. Laemmli, U. K. 1970. Cleavage of structural proteins during the assembly of the head of bacteriophage T4. Nature (Lond.). 227:680685 .

15. Summerhayes, I. C., Y. S. E. Cheng, T. T. Sun, and L. B. Chen. 1981. Expression of keratin and vimentin intermediate filaments in rabbit bladder epithelial cells at different stages of benzo (a) pyreneinduced neoplastic progression. J. Cell Biol. 90:63-69.

16. Rapp, H. J., and T. Borsos. 1970. Molecular Basis of Complement Action. Appleton-Century-Crofts, New York. 75.

17. Crossley, L. G. 1981. C3b inactivator and beta 1H. In Methods Enzymology 80, Part C, Academic Press, Inc. New York. 112-124.

18. Gerdes, J., U. Klatt, and H. Stein. 1980. Physicochemical characterization of $\mathrm{C} 3 \mathrm{~b}$ receptors isolated from human erythrocytes by immunoprecipitation. Immunol. 41:929-936.

19. Stossel, T. P., C. A. Alper, and F. S. Rosen. 1973. Serum dependent phagocytosis of paraffin oil emulsified with bacterial lipopolysaccharide. J. Exp. Med. 137:690-705.

20. Musson, R. A., and E. L. Becker. 1976. The inhibitory effect of chemotactic factors on erythrophagocytosis by human neutrophils. J. Immunol. 117:433-439.

21. Todd, R. F., E. L. Leeman, J. F. Daley, and S. F. Schlossman. 1983. Mo2: functional properties of antigen-bearing cells. Clin. Immunol. Immunopathol. 26:118-125.

22. Sanchez-Madrid, F., J. A. Nagy, E. Robbins, P. Simon, and 
T. A. Springer. 1983. Characterization of a human leukocyte differentiation antigen family with distinct alpha subunits and a common beta subunit; the lymphocyte-function associated antigen (LFA-1), the C3bi complement receptor (OKM1/Mac-1), and the P150,95 molecule. J. Exp. Med. 158:1785-1803.

23. Breard, J., E. L. Reinherz, C. O'Brian, and S. F. Schlossman. 1981. Delineation of an effector population responsible for natural killing and antibody-dependent cellular cytotoxicity in man. Clin. Immunol. Immunopathol. 18:145-150.

24. Gahmberg, C. G., L. C. Anderson, P. Ruutu, T. T. T. Timonen, A. Hanninen, P. Vuopio, and A. de la Chapelle. 1979. Decrease of the major high molecular weight surface glycoprotein of human granulocytes in monosomy-7 associated with defective chemotaxis. Blood. 54:401406.

25. Crowley, C. A., J. T. Curnutte, R. E. Rosin, J. Andre-Schwartz, J. I. Gallin, M. Klempner, R. Snyderman, S. S. Southwick, P. T. Stossel, and B. M. Babior. 1980. An inherited abnormality of neutrophil adhesion: its genetic transmission and its association with a missing protein. $N$. Engl. J. Med. 302:1163-1168.

26. Bowen, T. S., H. D. Ochs, L. C. Altman, T. H. Price, D. E. Van Epps, D. L. Brautigan, R. E. Rosin, W. D. Perkins, B. M. Babior, S. J. Klebanoff, and R. J. Wedgwood. 1982. Severe recurrent bacterial infections associated with defective adherence and chemotaxis in two patients with neutrophils deficient in a cell-associated glycoprotein. $J$. Pediatr. 101:932-940.
27. Ault, K., and T. A. Springer. 1981. Cross reaction of a rat-antimouse phagocyte-specific monoclonal antibody (anti-Mac-1) with human monocytes and natural killer cells. J. Immunol. 126:359-364.

28. Wright, S. D., P. E. Rao, W. C. Van Voorhis, L. S. Craigmyle, K. Iida, M. A. Talle, E. F. Westberg, G. Goldstein, and S. C. Silverstein. 1983. Identification of the $\mathrm{C} 3 \mathrm{bi}$ receptor of human leukocytes and macrophages by using monoclonal antibodies. Proc. Natl. Acad. Sci. USA. 80:5699-5703.

29. Medicus, R. G., J. Melamed, and M. A. Arnaout. 1983. Role of human factor I and $\mathrm{C} 3 \mathrm{~b}$ receptors in the cleavage of surface bound C3bi molecules. Eur. J. Immunol. 13:465-470.

30. Medof, M. E., K. Iida, C. Mold, and V. Nussenzweig. 1982. Unique role of the complement receptor CR1 in the degradation of C3b associated with immune complexes. J. Exp. Med. 155:1739-1754.

31. Ross, G. D., S. L. Newman, J. D. Lambris, J. E. Devery-Pocius, J. A. Kain, and P. J. Lachmann. 1983. Generation of three different fragments of bound C 3 with purified factor I or serum. II. Location of binding sites in the $\mathrm{C} 3$ fragments for factors $\mathrm{B}$ and $\mathrm{H}$, complement receptors, and bovine conglutinin. J. Exp. Med. 158:334-352.

32. Springer, T. A., D. Davignon, M. K. Ho, K. Kurzinger, E. Martz, and F. Sanchez-Madrid. 1982. LFA-1 and Lyt-2,3, molecules associated with T lymphocyte-mediated killing; and Mac-1, an LFA-1 homologue associated with complement receptor function. Immunol. Rev. 68:111-135. 